\title{
Suppression of hot carriers by nanoporous silicon for improved operation of a solar cell
}

\author{
${ }^{1}$ Ašmontas S., ${ }^{2}$ Fedorenko L., ${ }^{2}$ Vlasiuk V., ${ }^{2}$ Gorbanyuk T., ${ }^{2}$ Kostylyov V., \\ ${ }^{2}$ Lytovchenko V., ${ }^{1,3}$ * Gradauskas J., ${ }^{1}$ Sužiedèlis A., ${ }^{1}$ Šrmulis E., ${ }^{1}$ Žalys O. \\ and ${ }^{3}$ Masalskyi O. \\ ${ }^{1}$ Center for Physical Sciences and Technology, Sauletekio Avenue 3, 10257 \\ Vilnius, Lithuania,info@ftmc.lt \\ ${ }^{2}$ V. E. Lashkaryov Institute of Semiconductor Physics, National Academy of \\ Sciences of Ukraine, Nauky Avenue 41,03028 Kyiv, Ukraine, info@isp.kiev.ua \\ ${ }^{3}$ Vilnius Gediminas Technical University, Saulètekio Avenue 11, 10223 Vilnius, \\ Lithuania,vgtu@vgtu.lt
}

Received: 06.11 .2020

\begin{abstract}
The surface of a silicon solar cell is modified to improve its photovoltaic characteristics. Nanostructured porous silicon layer is formed on a front $\mathrm{n}^{+}$-type surface of a $\mathrm{p}-\mathrm{n}$ junction by means of electrochemical etching accompanied by illumination with a high-power light-emitting diode operating at the wavelength of $365 \mathrm{~nm}$. Addition of the porous layer results in considerable increase in the capacitive photovoltage across the $\mathrm{p}-\mathrm{n}$ junction. This increase is shown to be stipulated by reduced photonic losses due to anti-reflection coating effect of the porous layer, as well as by decreasing adverse effect of hot carriers on the photovoltage. Broadening of the spectrum of capacitive photovoltage towards the short-wavelength region was observed. This finding is associated with the gradedgap character of the porous layer and photovoltage formation across it as well as with increased absorption of high-energy photons in the porous layer and resulting weaker heating of free carriers.
\end{abstract}

Keywords: porous silicon, p-n junction, hot carriers, electrochemical etching, graded gap.

UDC: 535,621

\section{Introduction}

Rapid growth of global energy demand stimulates growing contribution of solar power into global power generation. Although photovoltaic energy presents important environmental advantages, it is limited by relatively high cost of solar cells' manufacturing [1]. As a result, researchers have been working extensively to make the solar energy less costly. At present, about $90 \%$ of worldwide solar cells are made from silicon [2]. The maximal conversion efficiency of singlejunction silicon solar cells produced in research laboratories reaches $26.6 \%$ [2], which is close to the theoretical limit, $33.3 \%$ [3].

In the recent years, various technologies and methods have been developed for improving the conversion efficiency of the silicon solar cells, including pyramid structures and anti-reflecting coatings. In order to reduce bulk recombination, high-quality silicon wafers are used when fabricating the solar cells. Moreover, surface passivation is employed to reduce surface recombination [2-4]. It is worth noting that the conversion efficiency of any solar cell is determined by efficient use of photons having the energies close to the forbidden-energy gap [5]. 
The photons with higher energies also create electronhole pairs, and the excess energy turns photogenerated carriers into hot carriers, thus causing a non-equilibrium distribution of carrier energies higher than that of the lattice. Even in the most efficient photovoltaic devices, at least $40 \%$ of the incident solar power is lost due to heat dissipation that occurs during thermalization of the hot carriers [6]. To utilize somehow these losses, Ross and Nozik [7] have suggested an idea of hotcarrier solar-energy convertor. Here photo-excited hot carriers can be extracted over a narrow range of energy-selective contacts at a rate faster than that at which they lose their energy and transfer it to the lattice. The theoretical efficiency of such a device can be very high, up to $66 \%$. Many theoretical and experimental works have been devoted to developing the hot-carrier solar cells $[8-12]$ because the theory shows that the maximum efficiency of these devices can reach even $85 \%$. However, the hot-carrier solar cells valuable for practical applications have not yet been developed. The main obstacle in their progress is high thermalization rate of photoheated carriers in the bulk region of semiconductor.

The impact of the hot carriers on photovoltage in nanoscopically thin hydrogenated p-i-n amorphous silicon has been studied in Ref. [10]. The increase in the open-circuit voltage $V_{\text {oc }}$ occurring with increased photon energy has been explained by extraction of the hot electrons generated near collector. Meanwhile, the observed decrease in the $V_{\text {oc }}$ parameter taking place in thick junctions has been explained by thermalization of the hot carriers and heating of the lattice. Indeed, heating of a $\mathrm{p}-\mathrm{n}$ junction causes formation of thermoelectromotive force, which has the polarity opposite to that of the classical photovoltage [5]. As a consequence, heating of the lattice decreases the conversion efficiency of the solar cells.

It is known [5] that the polarity of thermoelectromotive force of the hot carriers is also opposite to that of the classical photovoltage. To reduce the influence of hot carriers on the total photovoltage generated across a solar cell, a layered semiconductor structure can be used. A graded-gap semiconductor layer grown over a $\mathrm{p}-\mathrm{n}$ junction would decrease light-induced carrier heating and extend the effectively used solar radiation spectrum, since the polarity of the photovoltage across the graded-gap layer coincides with that of the classical photovoltage across the $\mathrm{p}-\mathrm{n}$ junction. In case of the silicon solar cells, this layer can be nanostructured porous $\mathrm{Si}$ (PSi) formed by means of electrochemical etching. The first application of PSi as an anti-reflection coating for the solar cells has been announced 38 years ago [13]. Since that time, different research groups have tested different porous materials with the aim of improving the conversion efficiency of photovoltaic devices [14-17]. It has been found $[14,15]$ that $\sim 0.5 \mu \mathrm{m}$-thick porous Si layer placed upon a polycrystalline wafer yields in the effective reflectance coefficients lower than $5 \%$ in the wavelength range $350-1150 \mathrm{~nm}$. A remarkable boost in the conversion efficiency (by 20\%) has been achieved for the solar cells where the PSi layer is introduced [17]. A sponge-like structure of porous silicon can cause quantum effects to play a fundamental role [18]. As a rule, the bandgap of PSi is larger than that of bulk $\mathrm{Si}$, due to the quantum-confinement effect. Therefore, the absorption of high-energy photons by porous silicon decreases the heating of free carriers and, hence, contributes to reduction of the negative influence of hot carriers on the efficiency of solar cells. It has also been found that PSi with structured nanocones reveals less optical absorption at the wavelengths ranging from 400 to $1000 \mathrm{~nm}$ [19]. Note that the gradedbandgap PSi structure with nanocones can increase the efficiency of Si-based solar cells whenever the polarity of the photovoltage operating across the graded-gap layer coincides with that of the classical photovoltage across the $\mathrm{p}-\mathrm{n}$ junction.

In this work we present the experimental results that elucidate the impact of the porous 
silicon layer on the photovoltage acting across the Si $\mathrm{p}-\mathrm{n}$ junction. Moreover, we discuss possible mechanisms that enhance the conversion efficiency and the peculiarities of our spectrally resolved data.

\section{Experimental}

The $\mathrm{p}-\mathrm{n}$ junction under test was produced with chemical-vapour deposition of an n-type epitaxial Si layer (the thickness of $2.5 \mu \mathrm{m}$ ) on a p-type silicon substrate. The electron density was equal to $6 \times 10^{17} \mathrm{~cm}^{-3}$ and the appropriate hole density amounted to $6 \times 10^{16} \mathrm{~cm}^{-3}$. To form the ohmic contact to $\mathrm{p}-\mathrm{Si}$, a thick additional $\mathrm{p}^{+}$layer (with the hole density $8 \times 10^{19} \mathrm{~cm}^{-3}$ ) was formed by diffusion of boron at the temperature of $950^{\circ} \mathrm{C}$, with subsequent thermal deposition of aluminium at $320^{\circ} \mathrm{C}$ and annealing performed at $560^{\circ} \mathrm{C}$ in the $\mathrm{Ar}$ atmosphere for $1 \mathrm{~min}$.

The nanoporous layer was synthesized on n-Si surface using an electrochemical etching. PSi is formed on the surface of the n-type silicon only if the reaction zone is supplied with the holes generated by illumination [20], which enables controlling the process of formation of the nanostructured PSi layer during electrochemical etching. The electrochemical etching of the $\mathrm{Si}$ surface was carried out in a transparent electrochemical cell with a Pt gauze electrode (see Fig. 1).

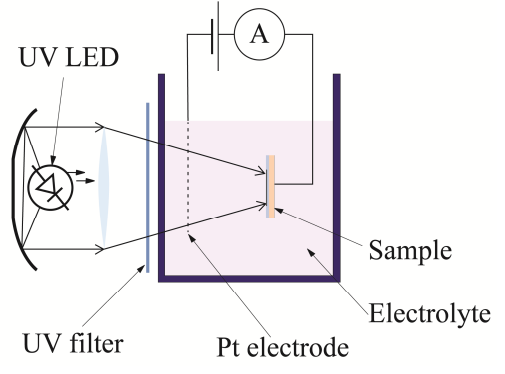

Fig. 1. The system used to form porous silicon.

The front $n$-surface of the $\mathrm{p}-\mathrm{n}$ junction was illuminated, using a high-power light-emitting diode operating at the wavelength of $365 \mathrm{~nm}$. This provided a small effective optical depth (a few nanometres) when generating electron-hole pairs at the front surface. The nanoporous silicon layer was shaped using photocatalytic electrochemical anodic process exhaustively described earlier in Ref. [21]. A 1:4 mixture of ethanol and a concentrated (49\%) HF acid was used as an electrolyte. The process was carried out in a galvanostatic mode at the current density kept constant for 3 min. Fig. 2 shows a schematic structure of the sample thus produced.

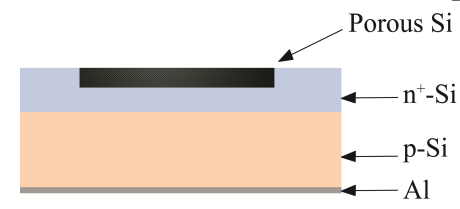

Fig. 2. Schematic view of $p-n$-junction solar cell with porous silicon layer.

The spectra of photoluminescence and capacitive photoelectromotive force were measured before and after formation of the nanoporous layers. The measurements were carried out at the Center for Testing of Photoconverters and Solar Batteries (V. E. Lashkaryov Institute of Semiconductor Physics, National Academy of Science, Ukraine). The morphology and topography of the porous layers were examined with a scanning electron microscope "Helios NanoLab 650" (FEI, Hillsboro, OR, USA) equipped with an energy-dispersive X-ray spectrometer "INCAEnergy" (Oxford Instruments, Abingdon, UK). 


\section{Results and discussion}

Fig. 3 presents scanning electron microscope images of our porous-silicon structure fabricated using photo-electrochemical etching of the n-Si surface, which has been illuminated with the ultraviolet light at the current density equal to $40 \mathrm{~mA} / \mathrm{cm}^{2}$. The surface topography demonstrates that PSi has a random structure (see Fig. 3a). A cross-sectional view of the PSi layer shown in Fig. $3 \mathrm{~b}$ indicates that the porosity is not homogeneous across the PSi layer, with the top of the structure being more porous than its bottom.

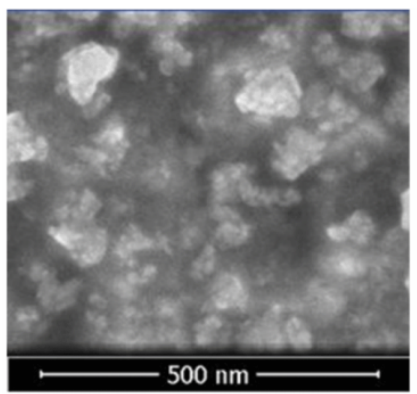

(a)

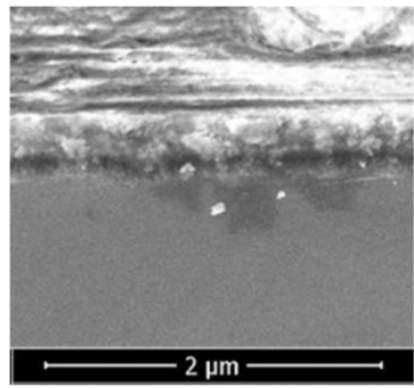

(b)

Fig. 3. Scanning electron microscope images of PSi: surface topography (a) and cross-section of n-Si/PSi structure (b). PSi is fabricated using photo-electrochemical etching of $n$-Si surface illuminated with ultraviolet light at $40 \mathrm{~mA} / \mathrm{cm}^{2}$.

The porosity and the thickness of the porous layer depend strongly on both the luminous intensity $\Phi$ at the front surface and the electric-current density in the electrolyte supported during electrochemical etching. The dependence of the thickness $d_{\mathrm{PSi}}$ of PSi layer on the electric-current density $J$ can be understood from Table 1 a.

Table 1. PSi thickness dPSi obtained for different electric-current densities at the constant luminous intensity $\Phi=8000 \mathrm{~W} / \mathrm{m}^{2}$ (a), and PSi thickness dPSi obtained for different luminous intensities at the constant electric-current density $\mathrm{J}=40 \mathrm{~mA} / \mathrm{cm}^{2}$ (b).

(a)

\begin{tabular}{cc}
\hline$J, \mathrm{~mA} / \mathrm{cm}^{2}$ & $d_{\mathrm{PSi}}, \mu \mathrm{m}$ \\
\hline 20 & 1.09 \\
30 & 1.7 \\
40 & 1.9 \\
\hline
\end{tabular}

(b)

\begin{tabular}{cc}
\hline$\Phi, \mathrm{W} / \mathrm{m}^{2}$ & $d_{\mathrm{PSi}}, \mu \mathrm{m}$ \\
\hline 980 & 0.3 \\
2600 & 1.36 \\
9090 & 2.14
\end{tabular}

It is clear that $d_{\mathrm{PSi}}$ is not a linear function of the current density: it tends to become saturated at stronger currents. The dependence of $d_{\mathrm{PSi}}$ on the luminous intensity is presented in Table 1b. A high absorption coefficient $\left(\alpha=1.2 \times 10^{6} \mathrm{~cm}^{-1}\right.$ at $365 \mathrm{~nm}$ [22]) and a small diffusion length of the generated electron-hole pairs allow one to control both the porosity and the thickness of the PSi layers by changing either the luminous intensity or the current density. Both the porosity and the thickness of PSi layers increase with increasing luminous intensity and electric-current density.

It is known that the photoluminescence intensity increases with increasing porosity [23]. The photoluminescence spectra of the $\mathrm{n}^{+}$-type silicon etched electrochemically at different current densities are depicted in Fig. 4. The photoluminescence intensity becomes higher for the porous layers formed under higher current densities, while the peak wavelength almost does not change under this condition, being close to $660 \mathrm{~nm}$. The photoluminescence observed by us belongs to a so-called ' $\mathrm{S}$ ' band, which is typical for electrochemically etched porous silicon [23]. 


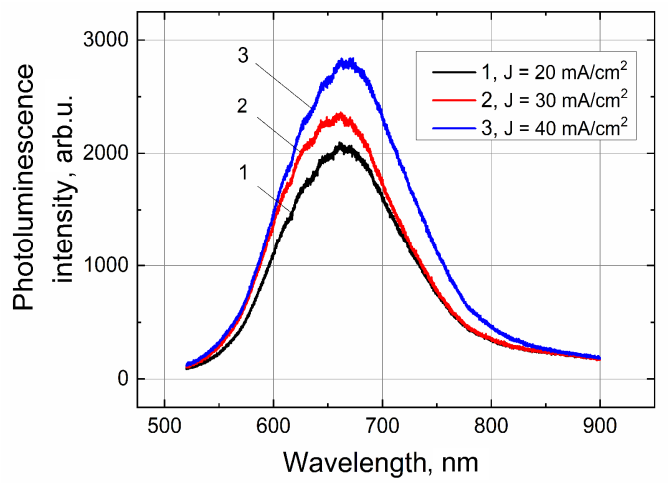

Fig. 4. Photoluminescence spectra of $\mathrm{n}^{+}$type silicon electrochemically etched at different current densities.

Photoelectric properties of the $\mathrm{p}-\mathrm{n}$ junction have been investigated using a capacitive photovoltage spectroscopy technique described in Ref. [24]. Spectral dependences of the capacitive photovoltage across the Si p-n junction are displayed in Fig. 5 for the alternative cases of presence or absence of the porous layer. It is obvious that the photovoltage is strongly influenced by this layer. The increase in the capacitive photovoltage can be stipulated by at least four different factors. (i) The PSi layer reduces the effective reflectance coefficient from $38 \%$ to less than $5 \%[14,15]$. Then the anti-reflection coating effect of PSi supports the capacitive photovoltage by means of reduction of photon losses. (ii) The PSi layer makes the $\mathrm{n}^{+}$region of the $\mathrm{p}-\mathrm{n}$ junction thinner, which works in favour of reduced recombination of photo-generated carriers. (iii) The nanostructured PSi layer leads to formation of a graded-gap structure, with a resulting increase in the photovoltage across it (see the processes denoted as 1 and 2 in Fig. 6) [25]; having the same polarity and being added to the classical photovoltage (see the process 3 ), the graded-gap photovoltage can increase the total photovoltage. Moreover, the effective electric field of the graded band of the nanostructured PSi layer accelerates photo-generated carriers (the process 2), so that their transit time becomes shorter than the recombination time [25]. In this way, the photogenerated carriers can travel through the porous $\mathrm{n}^{+}$-type layer and avoid significant recombination. (iv) The absorption of high-energy photons in the nanoporous layer (see the process 1 in Fig. 6) reduces the negative effect of the hot-carrier photovoltage with the opposite polarity (the process 4) on the net photovoltage across the Si p-n junction [5]. Diminution of the hot-carrier effect can lead to extending of the solar-radiation spectrum effectively used in practice.

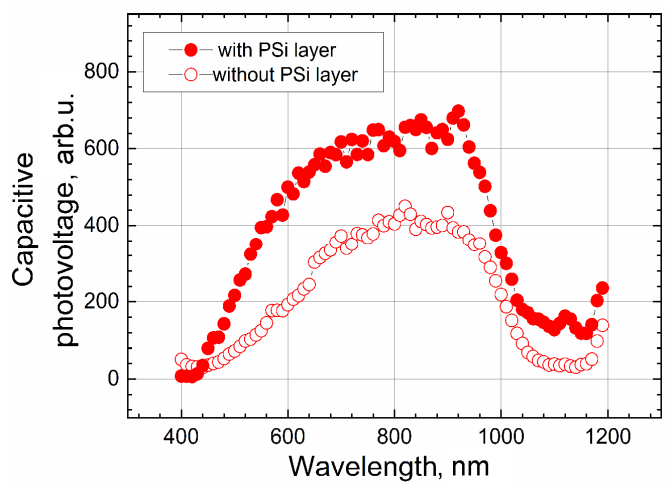

Fig. 5. Spectra of capacitive photovoltage across silicon $p$-n junction without (open dots) and with (solid dots) porous layer formed at $40 \mathrm{~mA} / \mathrm{cm}^{2}$ current density and $8000 \mathrm{~W} / \mathrm{m}^{2}$ intensity (see details in the text).

Ukr. J. Phys. Opt. 2020, Volume 21, Issue 4 


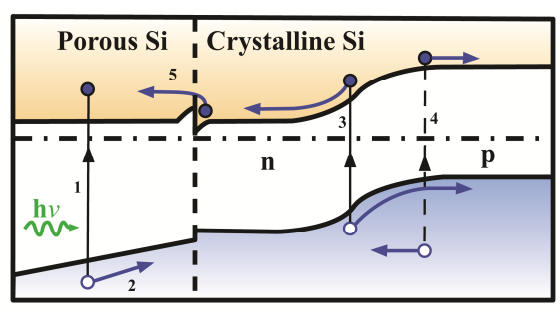

Fig. 6. Physical processes producing different types of photovoltage in the nanoporous silicon-covered $p-n$ junction: 1 - generation of electron-hole pair by a high-energy photon, 2 - hole drift in the electric field of graded-gap layer of PSi, 3 - classical generation-induced photovoltage, 4 - generation of electron-hole pair by a high-energy photon and the corresponding hot-carrier photovoltage across $p-n$ junction, and 5 - rise of photovoltage at the interface PSi / crystalline Si.

Fig. 7 shows the normalized spectral dependences of the photovoltage across our Si $\mathrm{p}-\mathrm{n}$ junction detected when the nanostructured PSi layer is present or absent. It is evident that the above layer widens the photovoltage spectrum. The photovoltage in the short-wavelength region is, most probably, stipulated by both appearance of the graded-gap photovoltage (the processes 1 and 2 in Fig. 6) and reduction of the negative hot-carrier effect. The additional hot-carrier photovoltage available across the $\mathrm{PSi} / \mathrm{n}-\mathrm{Si}$ interface (the process 5) can be the reason for extending spectrum in the long-wavelength region [26].

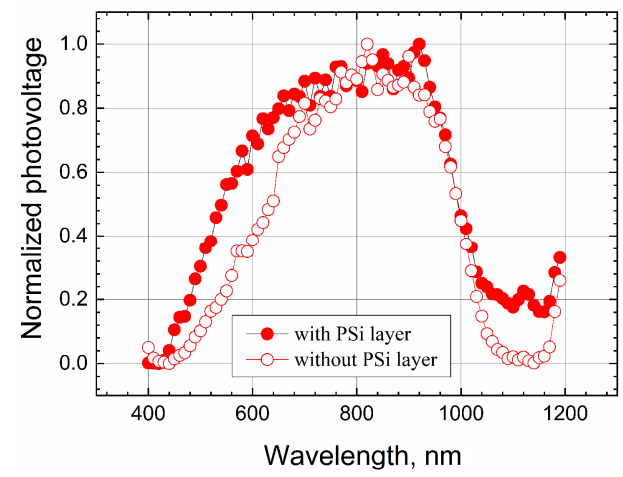

Fig. 7. Normalized spectra of capacitive photovoltage across Si p-n junction with (solid dots) and without (open dots) porous layer.

\section{Conclusion}

We have demonstrated that the nanoporous silicon layer formed on the front surface of the $p-n$ junction can improve the performance of silicon solar cells. Introduction of the porous layer into the $\mathrm{n}^{+}$-type silicon by means of photocatalytic electrochemical anodic process increases the magnitude of photovoltage across the Si $\mathrm{p}-\mathrm{n}$ junction and widens its spectrum, if compared to the layerless samples. More effective absorption of the high-energy photons and reduced negative impact of the hot carriers on the photovoltage are supposed to be the reasons of this improvement.

\section{Acknowledgement}

This work was supported by the Research Council of Lithuania under Grant No 01.2.2-LMT-K718-01-0050.

\section{References}

1. Taco-Ugsha M A, Santacruz C P and Espinoza-Montero P J, 2020. Natural dyes from Mortiño (Vaccinium floribundum) as sensitizers in solar cells. Energies. 13: 785-796. 
2. Yu C, Xu S, Yao J and Han S, 2018. Recent advances in and new perspectives on crystalline silicon solar cells with carrier-selective passivation contacts. Crystals. 8: 430-441.

3. Sachenko A, Kostylyov V, Sokolovskyi I and Evstigneev M, 2020. Effect of temperature on limit photoconversion efficiency in silicon solar cells. IEEE J. Photovoltaics. 10: 63-69.

4. Bullock J, Wan Y, Xu Z, Essig S, Hettick M and Wang H, 2018. Stable dopant-free asymmetric heterocontact silicon solar cells with efficiencies above 20\%. ACS Energy Lett. 3: 508-513.

5. Ašmontas S, Gradauskas J, Sužiedelis A, Šilènas A, Širmulis E, Švedas V, Vaičikauskas V and Žalys O, 2018. Hot carrier impact on photovoltage formation in solar cells. Appl. Phys. Lett. 113: 071103.

6. Le Bris A, Lombez L, Laribi S, Boissier G, Cristol P and Guillemoles J-F, 2012. Thermalisation rate study of GaSb-based heterostructures by continuous wave photoluminescence and their potential as hot carrier solar cell absorbers. Energy Environ. Sci. 5: 6225-6232.

7. Ross R T and Nozik A J, 1982. Efficiency of hot - carrier solar energy converters. J. Appl. Phys. 53: 3813-3818.

8. Neges M, Schwarzburg K and Willig F, 2017. Monte Carlo simulation of energy loss and collection of hot charge carriers, first step towards a more realistic hot-carrier solar energy converter. Solar Energy Mater. and Solar Cells. 90: 2107-2128.

9. Conibeer G J, Köning D, Green M A and Guillemoles J F, 2008. Slowing of carrier cooling in hot carrier solar cells. Thin Solid Films. 516: 6948-6953.

10. Kempa K, Naughton M J, Ren Z F, Herczynsky A, Kirkpatrick T, Rybczynski J and Gao Y, 2009. Hot electron effect in nanoscopically thin photovoltaic junctions. Appl. Phys. Lett. 95: 233121.

11. Takeda Y and Motohiro T, 2011. Highly efficient solar cells using hot carriers generated by two-step excitation. Solar Energy Mater. and Solar Cells. 95: 2638-2644.

12. Rodière J, Lombez L, Le Corre A, Durand $O$ and Guillemoles J-F, 2015. Experimental evidence of hot carriers solar cell operation in multi-quantum wells heterostructures. Appl. Phys. Lett. 106: 183901.

13. Prasad A, Balakrishnan S, Jain S K and Jain G S, 1982. Porous silicon oxide anti - reflection coating for solar cells. J. Electrochem. Soc. 129: 596-599.

14. Menna P, Di Francia G and La Ferrara V, 1995. Porous silicon in solar cells: A review and a description of its application as an AR coating. Solar Energy Mater. and Solar Cells. 129: 13-24.

15. Lipinski M, Bastide S, Panek P and Levy-Clement C, 2003. Porous silicon antireflection coating by electrochemical and chemical etching for silicon solar cell manufacturing. Phys. Stat. Sol. 197: 512-517.

16. Striemer C C and Fauchet P M, 2003. Dynamic etching of silicon for solar cell applications. Phys. Stat. Sol. 197: 502-506.

17. Dzhafarov T D, Aslanov S S, Ragimov S H, Sadigov M S and Yuksel S A, 2012. Effect of nanoporous silicon coating on silicon solar cell performance. Vacuum. 86: 1875-1879.

18. Bisi O, Ossicini S and Pavesi L, 2000. Porous silicon: a quantum sponge structure for silicon based optoelectronics. Surf. Sci. Rep. 38: 1-126.

19. Zhu J, Yu Z, Burhard G F, Hsu C M, Connor S T, Xu Y, Wang Q, McGehee M, Fan Sh and Cui Y, 2009. Optical absorption enhancement in amorphous silicon nanowire and nanocone arrays. Nano Lett. 9: 279-282.

20. Lehman V and Föll H, 1990. Formation mechanism and properties of electrochemically etched trenches in n-type silicon. J. Electrochem. Soc. 137: 653-659.

Ukr. J. Phys. Opt. 2020, Volume 21, Issue 4 
21. Lytovchenko V G, Gorbanyuk T I, Kladko V P, Sarikov A V, Safriuk N V, Fedorenko L L, Ašmontas S, Gradauskas J, Širmulis E and Žalys O, 2017. Preparation and study of porous Si surfaces obtained using the electrochemical method. Semiconduct. Phys. Quant. Electron. and Optoelectron. 20: 385-395.

22. Dargys A and Kundrotas J. Handbook on physical properties of $\mathrm{Ge}, \mathrm{Si}, \mathrm{GaAs}$ and $\mathrm{InP}$. Vilnius: Science and Encyclopedia Publishers (1994).

23. Gelloz B J. Luminescent properties of porous silicon. In Porous silicon: from formation to application: formation and properties. Ed. by G.Korotcenkov, London: CRC Press (2016).

24. Karpovich I A and Filatov D O, 1996. Diagnostics of the quantum well heterostructures by the capacitive photovoltage spectroscopy method. Semiconductors. 30: 1745-1755.

25. Vashpanov Y and Jeong J I, 2010. Optical absorption and photoelectron collection properties of silicon wafers with conical quantum nanocrystals structure. Nano-Micro Lett. 2: 149-153.

26. Gradauskas J, Šatkovskis, E, Česnys, A, Stupakova J, Sužiedèlis A, 2008. Charge carrier heating effect in porous silicon structures investigated by microwaves. Acta Phys.Pol. A 113: 993-996.

Ašmontas S., Fedorenko L., Vlasiuk V., Gorbanyuk T., Kostylyov V., Lytovchenko V., Gradauskas J., Sužiedèlis A., Širmulis E., Žalys O. and Masalskyi O. 2020. Suppression of hot carriers by nanoporous silicon for improved operation of a solar cell. Ukr.J.Phys.Opt. 21: $207-$ 214. doi: $10.3116 / 16091833 / 21 / 4 / 207 / 2020$

Анотація. Поверхня кремнісвого сонячного елемента була модифікована для поліпшення його фотоелектричних характеристик. На передній $n^{+}$-типу поверхні $p-n$ переходу був сформований наноструктурований шар пористого кремнію за допомогою електрохімічного травлення, яке супроводжувалося освітленням потужним світлодіодом, що працював на довжині хвилі 365 нм. Додавання пористого шару призводить до значного збільшення ємнісної фотонапруги на $p-n$ переході. Показано, що це збільшення обумовлене зменшенням втрат фотонів внаслідок дії противовідбивного покриття пористого шару, а також зменшенням несприятливого впливу гарячих носіїв на фотонапругу. Виявлено, що розширення спектру ємнісної фотонапруги в короткохвильову область. Це пов'язано зі варизонним характером пористого шару і сформованої фотоелектричної напруги на ньому та збільшенням поглинання високоенергетичних фотонів у пористому шарі та як результат зменшене нагрівання вільних носіїв. 